\title{
ANALISA PENYEIMBANGAN LINTASAN PERAKITAN PADA PROSES PEMBUATAN T-SHIRT DI DEPARTEMEN ASSEMBLING DENGAN MENGGUNAKAN METODA HEGELSON - BIRNIE DAN METODA KILLBRIDGE - WESTER PT. CALADI LIMA SEMBILAN (C-59) BANDUNG
}

\author{
Dini Yulianti \\ Universitas Bandung Raya \\ Diniyulianti_17@yahoo.com
}

\begin{abstract}
Abstrak - Line balancing adalah suatu usaha mengatur lintasan produksi dengan tujuan merencanakan keseimbangan lintasan stasiun kerja (work station) pada tingkat shop floor, guna memperoleh tingkat efisiensi kerja yang tinggi. Proses pembuatan T-Shirt di PT. Caladi Lima Sembilan (C-59) memiliki proses operasi yang tidak seimbang, sehingga terjadi penumpukan barang setengah jadi pada suatu stasiun kerja dan adanya waktu menganggur (idle time) pada suatu proses operasi karena adanya antrian barang setengah jadi pada suatu mesin (bottle neck). Metode Line Balancing yang digunakan adalah metode Hegelson-Birnie yang didasarkan pada prioritas bobot posisi setiap operasi/elemen kerja dan metode Killbridge-Wester yang didasarkan pada pembagian wilayah. Kedua metode-metode yang digunakan sama-sama memberikan hasil yang optimal dalam mengatasi persoalan line balancing. Pada Metode Hegelson-Birnie dengan waktu siklus 30 detik diperoleh rata-rata efisiensi sebesar 93,33\% dengan idle time 16 detik dan balance delay sebesar 6,67\%, selain itu adanya pengurangan jumlah stasiun kerja dari 16 stasiun kerja menjadi 8 stasiun kerja. Sedangkan pada Metode Killbridge-Wester dengan waktu siklus 40 detik diperoleh rata-rata efisiensi sebesar $80,00 \%$ dengan idle time 56 detik dan balance delay sebesar 20\%, selain itu adanya pengurangan jumlah stasiun kerja dari 16 stasiun kerja menjadi 7 stasiun kerja. Dari perbandingan kedua metode tersebut yang merupakan solusi terbaik di dalam penerapan metoda line balancing pada pembuatan T-Shirt di PT. Caladi Lima Sembilan (C-59) adalah metode Hegelson-Birnie.
\end{abstract}

Kata Kunci : keseimbangan lintasan, waktu menganggur, efisiensi

Abstract - Line balancing is an attempt to manage the production line by balancing the work station line on the shop floor level all in order to achieve high work efficiency. The T-shirt production in PT. Caladi Lima Sembilan (C59) had an unbalanced operation process, creating accumulation of half-finished products on a work station and idle time on an operation process due to the queue of the half-finished products on a machine (bottleneck). Line balancing method that was used was the Hegelson - Birnie method which was based on the position weight priority of each work operation/elemen, and Killbridge - Wester method which was based on regional division. Both of the methods used equally give the optimalresult in solving the line balancing problem. Using the Hegelson - Birnie method with cycle time of 30 second we obtain average efficiency of 93,33\% with idle time of 16 second and balanced delay of $6,67 \%$, and the decrease of the work station from 16 station to 8 . Meanwhile, by using Killbridge - Wester method with cycle time of 40 second we obtained average efficiency of $80,00 \%$ with idle time of 56 second and balance delay of $20 \%$ and the decrease of the work station from 16 to 7 . Comparing between the two methods, we conclude that the best solution to the line balancing method of the T-shirt production in PT. Caladi Lima Sembilan (C59) was given by the Hegelson - Birnie method

Keywords : Line Balancing, idle time, Efficiency

\section{PENDAHULUAN}

Pada suatu industri manufakturing, produk akan mengalami berbagai macam proses, proses-proses tersebut dapat meliputi : perencanaan produksi, analisa produksi, strategi proses, teknik tata cara kerja, dan lain sebagainya. Perencanaan produksi merupakan suatu perencanaan dan pengorganisasian tenaga kerja, material, mesin, dan peralatan lainnya, serta modal yang diperlukan untuk memproduksi suatu produk pada periode tertentu dimasa yang akan datang sesuai dengan kebutuhan. Hal tersebut dapat dilakukan pada lantai produksi (shop floor) dengan suatu proses manufacturing.

Dalam suatu perusahaan dengan tipe produksi massal yang melibatkan sejumlah besar komponen yang harus dirakit, perencanaan produksi memegang peranan penting dalam pembuatan penjadwalan produksi, terutama dalam pengaturan operasi-operasi atau penugasan kerja yang harus dilakukan. Bila pengaturan dan perencanaan tidak tepat maka setiap stasiun kerja di lintasan perakitan mempunyai kecepatan produksi yang berbeda. Hal ini akan mengakibatkan lintasan perakitan tersebut tidak efisien, karena terjadi penumpukan material atau produk setengah jadi di antara stasiun kerja yang tidak berimbang kecepatan produksinya. Akibat sampingan lainnya adalah kompensasi ongkosongkos yang hilang serta akibat psikologis yang negatif bagi pekerja.

Pada umumnya, perencanaan suatu keseimbangan di dalam sebuah lintasan perakitan merupakan usaha yang bertujuan untuk mencapai suatu kapasitas 
produksi yang optimal, dimana tidak terjadi penghamburan fasilitas.

\section{Identifikasi Masalah}

PT. Caladi lima sembilan atau disebut dengan C-59, melakukan aktivitas produksi dalam pembuatan kaos (T-shirt), Polo Shirt, Jaket, Sweater, dan training, juga membuat asesoris seperti Topi dan dompet. Produk tersebut dibuat dalam 2 karakteristik yaitu secara order dan secara massal (retail). Produk Tshirt diproduksi secara retail, sedangkan produk Polo Shirt, jacket, sweater, dan training, juga asesoris seperti topi dan dompet, diproduksi sesuai dengan order. Penelitian hanya dilakukan pada T-Shirt yang diproduksi secara retail. Dengan kapasitas produksi per bulannya adalah 78750 pieces. Pembuatan TShirt ini terdiri dari beberapa operasi, dimana operasi yang satu dengan operasi yang lainnya saling bergantungan (dependent). Artinya jika salah satu operasi terhambat, maka operasi berikutnya akan terhambat. Di samping itu, tiap-tiap operasi memiliki waktu proses yang berbeda, oleh karena itu lintasan perakitan menjadi tidak seimbang dan tidak efisien.

Persoalan keseimbangan lintasan perakitan bermula dari adanya kombinasi penugasan kerja pada operator atau group operator yang menempati tempat kerja tertentu. Arena penugasan elemen kerja yang berbeda akan menyebabkan perbedaan dalam sejumlah waktu yang tidak produktif dan variasi jumlah pekerja yang dibutuhkan untuk menghasilkan output produksi tertentu di dalam suatu lintasan perakitan. Masalah kombinasi tersebut menjadi masalah di dalam menyeimbangkan lintasan perakitan, menyeimbangkan operasi atau stasiun kerja dengan tujuan untuk mendapatkan waktu yang sama di antara stasiun kerja sesuai dengan kecepatan produksi yang diinginkan. Dan yang menjadi masalah dalam perusahaan ini adalah adanya penumpukan barang setengah jadi pada suatu stasiun kerja dan adanya waktu menganggur (idle time) pada suatu proses operasi karena adanya antrian barang setengah jadi pada suatu mesin (bottle neck).

Untuk menanggulangi masalah tersebut, maka perlu diadakan suatu penelitian untuk menganalisa waktu proses setiap operasi dan stasiun kerja yang ada dalam proses pembuatan T-Shirt ini, serta berusaha untuk memberikan usulan dan perbaikan lintasan perakitan sehingga terjadi keseimbangan lintasan di antara proses operasi pada tiap-tiap operasi dan stasiun kerjanya. Dan untuk menghindari atau mengurangi terjadinya bottle neck, sehingga memperoleh tingkat efisien kerja yang tinggi dan kapasitas produksi yang optimal.

Maka Identifikasi penelitian ini adalah sebagai berikut :

1. Bagaimana menganalisa keseimbangan lintasan perakitan t-shirt dengan metode Hiegelson Birnie dan Killbride - Wester di PT. C59 Bandung ?
2. Metode mana yang terbaik dipilih untuk menguntungkan perusahaan?

\section{Tujuan dan Kegunaan Pemecahan Masalah}

Secara umum tujuan dari penelitian ini adalah merencanakan keseimbangan lintasan stasiun kerja (work station) pada tingkat shop floor, guna memperoleh tingkat efisiensi kerja yang tinggi. Penelitian ini juga dilakukan untuk :

1. Untuk dapat menganalisa keseimbangan lintasan perakitan t-shirt dengan metode Hiegelson Birnie dan Killbride - Wester di PT. C59 Bandung.

2. Untuk dapat mengetahui metoda yang terbaik untuk line balancing PT. C59 sehingga menghasilkan hasil yang optimal.

\section{KAJIAN PUSTAKA DAN PERUMUSAN HIPOTESIS}

Rony Prabowo. Penerapan Konsep Line Balancing untuk mencapai efisiensi kerja yang optimal pada setiap stasiun kerja pada PT. HM. Sampoerna Tbk. ISSN. 1411-7010. volume 20 no.2, desember 2016. Jurnal ini menjelaskan tentang line balancing dengan metode bobot posisi (method ranked positional weight).

Nuchsara Kriengkorakot and Nalin Piantong. 2007. The Assembly Line Balancing Problem : review articles. International Journal of Production Research, vol. 34 no.2 (133 - 140) march - april 2007. Menjelaskan tentang line balancing dengan assembly terdapat metoda killbridge dan linier programming.

Dari acuan kedua jurnal tersebut peneliti berusaha menyempurnakan jurnal ini menggunakan dua metoda heuristic Hegelson Birnie dan Killbridge Wester. Karena kedua metoda tersebut pemecahannya lebih baik dan cepat, lebih mudah dibandingkan dengan pendekatan lainnya.

Dan penelitian jurnal ini merupakan proses produksi massal yang mempunyai OPC maka dari itu inilah alasan menggunakan metode Hegelson Birnie dan Killbridge Wester.

\section{METODE PENELITIAN}




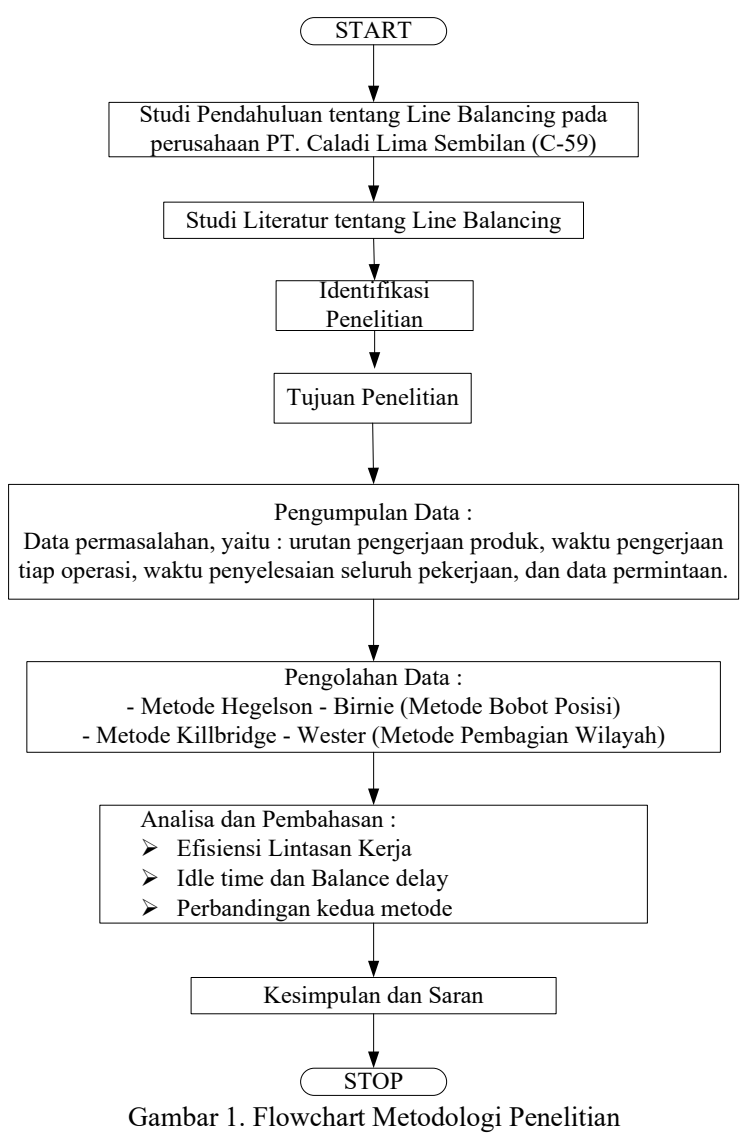

Metoda yang digunakan dalam penelitian ini adalah metoda Hegelson-Birnie dan metoda KillbridgeWester, karena selain mudah dalam penerapannya, hasil perhitungannya juga cukup efektif untuk perbaikan sistem yang sudah ada. Dengan kedua metoda tersebut dilakukan pengaturan dan pengelompokkan elemen-elemen pekerjaan (operasi) dalam rangka memperoleh lintasan yang seimbang dan efisiensi kerja yang tinggi, serta mengurangi atau menghindari terjadinya bottle neck.

Metoda Hegelson-Birnie (Rank Positional Weight) Metoda ini biasa juga disebut metoda pengurutan bobot posisi. Pengertian bobot posisi dari suatu operasi adalah jumlah waktu pelaksanaan semua operasi yang mengikutinya. Langkah pertama dari metoda ini adalah menentukan diagram kebergantungan (precedence diagram), kemudian kita menentukan bobot posisi dari tugas-tugas yang ada, dan susun urutan tugas dari bobot posisi yang terbesar ke yang terkecil. Untuk lebih jelasnya, langkah-langkah pemecahan masalah dengan metoda ini adalah sebagai berikut (Heizer dan Render, 2006)

a). Membuat Precedence Diagram/Network.

b). Menyajikan keadaan ke dalam Precedence Matrix.

c). Menghitung Positional Weight dan meranking berdasarkan bobot yang terbesar, antara lain :

- Position Weight Before Ranking

- Position Weight After Ranking

d). Menentukan Cycle Time, yaitu :
$\Sigma$ Waktu Proses

Waktu Siklus $=\underset{\Sigma \text { Work Station }}{ }$

e). Melakukan pengelompokkan berdasarkan Work Station.

f). Menghitung efisiensi tiap-tiap lintasan atau work station, dan efisiensi rata-rata dari keseluruhan lintasan.

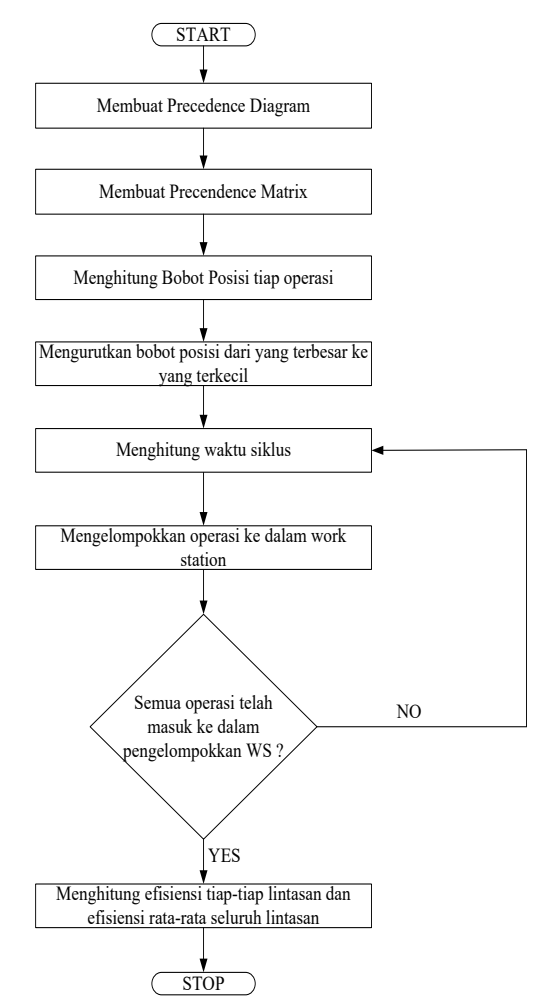

Gambar 2. Flowchart Langkah - langkah metode Hegelson Birnie

\section{Metoda Killbridge-Wester (Region Approach)}

Metoda Killbridge-Wester biasa juga disebut metoda pembagian wilayah, dimana dalam metoda ini Precedence Diagram beserta elemen pekerjaannya dikelompokkan dalam sebuah kolom (wilayah). Kolom/wilayah paling kanan akan mendapat prioritas utama dalam pengaturan/pengelompokan operasioperasi ke dalam work station. Metoda ini adalah perbaikan dan pengembangan dari pendekatan Hegelson-Birnie dan diperkenalkan pertama kali oleh Mansoor. Pendekatan ini memungkinkan untuk mendapat solusi keseimbangan lintasan yang optimal dengan cara mengganti pekerjaan antar stasiun kerja untuk mencapai keseimbangan. Untuk lebih jelasnya langkah-langkah pemecahan masalah dengan metoda ini adalah sebagai berikut :

a). Membuat Precedence Diagram.

b). Menentukan Cycle Time, yaitu :

$$
\Sigma \text { Waktu Proses }
$$

Waktu Siklus $=$

$$
\Sigma \text { Work Station }
$$

c). Melakukan pengelompokkan elemen kerja terhadap kolom-kolom. 
d). Melakukan pengelompokkan elemen kerja tiap kolom terhadap Work Station.

e). Mengalokasikan elemen-elemen kerja ke dalam Work Station.

f). Menghitung efisiensi tiap-tiap lintasan atau work station, dan efisiensi rata-rata dari keseluruhan lintasan.

Setelah metoda Hegelson-Birnie (Rank Positional Weight) dan metoda Killbridge-Wester (Region Approach) digunakan, kemudian membandingkan kedua metoda tersebut dan mencari yang terbaik dengan kriteria unit produksi yang terbesar dan menghasilkan efisiensi yang terbesar.

Dalam pemecahan masalah Line Balancing, kita perlu beberapa informasi berikut ini, yaitu antara lain

1. Peta Proses Operasi (OPC)

2. Waktu pengerjaan setiap operasi/work elemen

3. Waktu yang tersedia dalam mengerjakan seluruh operasi yang ada
4. Data permintaan serta jumlah tenaga kerja

\section{HASIL DAN PEMBAHASAN}

Kapasitas produksi perusahaan ini rata-rata 78750 pieces/bulan, yang berarti selama setahun 945000 pieces. Dan data waktu yang tersedia untuk memenuhinya selama satu tahun sebanyak 300 hari dengan 14 jam kerja/hari.

Pendeskripsian pembuatan T-Shirt dapat diperjelas dengan pembuatan Peta Proses Operasi (OPC). Peta Proses Operasi ini merupakan suatu diagram yang menggambarkan langkah-langkah proses yang akan dialami bahan (bahan baku) mengenai urutan-urutan operasi dan pemeriksaannya.

Peta ini menurut pertimbangan keteranganketerangan yang patut dipertimbangkan untuk menganalisa waktu dan tempat (locate) yang diperlukan. Digunakan untuk mengetahui proses yang terjadi secara keseluruhan sebelum dilakukan penelitian secara terperinci. Untuk lebih jelasnya dapat dilihat pada gambar sebagai berikut :

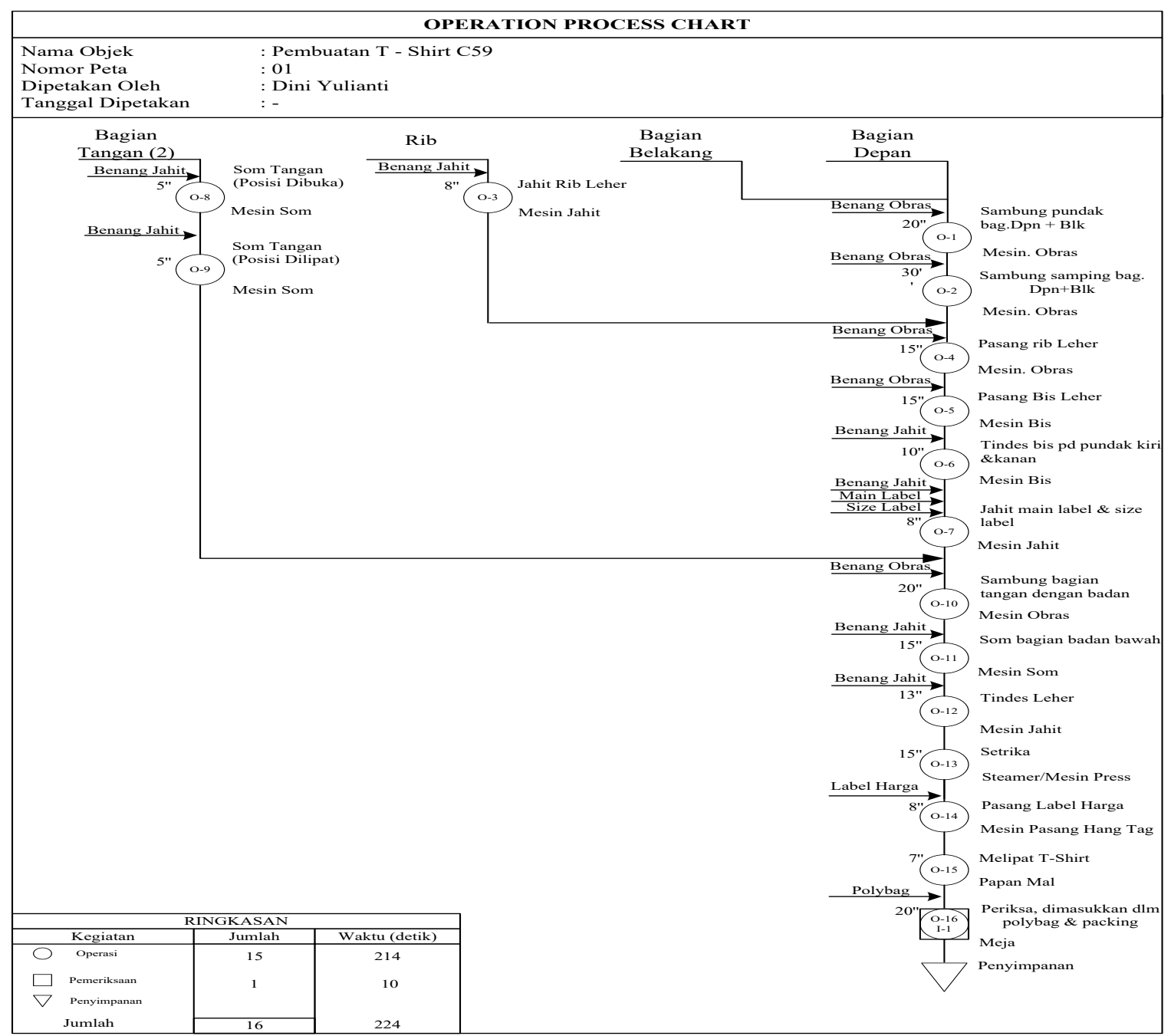

Sumber : Data Olahan

Gambar 3. Operation Process Chart Tshirt C59 


\section{Penentuan Waktu Siklus}

Waktu Siklus yang akan digunakan dalam penyeimbangan lintasan perakitan pembuatan T-shirt ini, yaitu :

\section{Waktu Siklus}

Waktu siklus ditentukan berdasarkan pesanan yang ada atau kapasitas produksi perusahaan sepatu yaitu 78750 pieces/bulan.

- Waktu/jam kerja yang tersedia (sebanyak 300 hari kerja)

$=300$ hari $\times 14$ jam/hari $\times 3600$ detik

$=15120000$ detik

- Target produksi selama 1 tahun $=78750$ pieces/bulan x 12 bulan= 945000 pieces

- Waktu siklus = jam kerja yang tersedia / target produksi $=15120000 / 945000=16$ detik

Pada metode Hiegelson-Birnie, didapatkan waktu siklus 16 detik, apabila waktu siklus tersebut digunakan, maka akan ada waktu operasi yang tidak dapat masuk ke dalam stasiun kerja. Oleh karena itu, agar semua operasi masuk ke dalam pengelompokkan stasiun kerja, maka waktu siklus yang digunakan ditentukan berdasarkan waktu operasi yang paling besar yaitu 30 detik.

\section{Penyeimbangan Lintasan Produksi}

Setelah waktu siklus untuk pembuatan produk TShirt ditentukan, maka langkah selanjutnya adalah melakukan penyeimbangan lintasan produksi untuk mendapatkan penggunaan fasilitas dan tenaga kerja yang efisien.
Metode yang digunakan untuk melakukan penyeimbangan lintasan produksi ini adalah dengan pendekatan Heuristik. Pendekatan Heuristik yang digunakan untuk melakukan penyeimbangan pada pembahasan ini adalah metode Hegelson-Birnie dan metode Killbridge-Wester (Pembagian Wilayah), dimana hasil dari kedua metode tersebut akan dibandingkan, kemudian dipilih metode yang sesuai dengan kondisi yang ada serta memberikan efisiensi kerja yang paling baik. Dalam penelitian ini digunakan Metode Hegelson-Birnie dan KillbridgeWester, karena kedua metode ini merupakan metode Heuristik yang cukup sederhana dan mudah diterapkan, serta lebih cepat dalam pengerjaannya. Sebelum dilakukan penyeimbangan, susunan stasiun kerja dan efisiensi dari stasiun kerja.

\section{Metode Hegelson Birnie (Metode Bobot Posisi)}

Langkah awal yang dilakukan dalam Metode Bobot Posisi ini adalah penyusunan Precedence Matriks, setelah itu diberikan bobot untuk masing-masing operasi yaitu dengan menjumlahkan waktu operasi yang megikuti operasi tersebut ditambah dengan waktu operasi itu sendiri. Setelah penyusunan bobot ini dari masing-masing operasi kemudian dilakukan penentuan ranking dari setiap operasi, dimana bobot terbesar merupakan ranking pertama, dan seterusnya. Adapun pembagian bobot yang telah diurutkan dan ranking serta waktu dari setiap operasi.

Langkah selanjutnya adalah menyusun stasiun kerja berdasarkan waktu siklus yang sudah ditetapkan dan kemudian membuat lintasan stasiun.

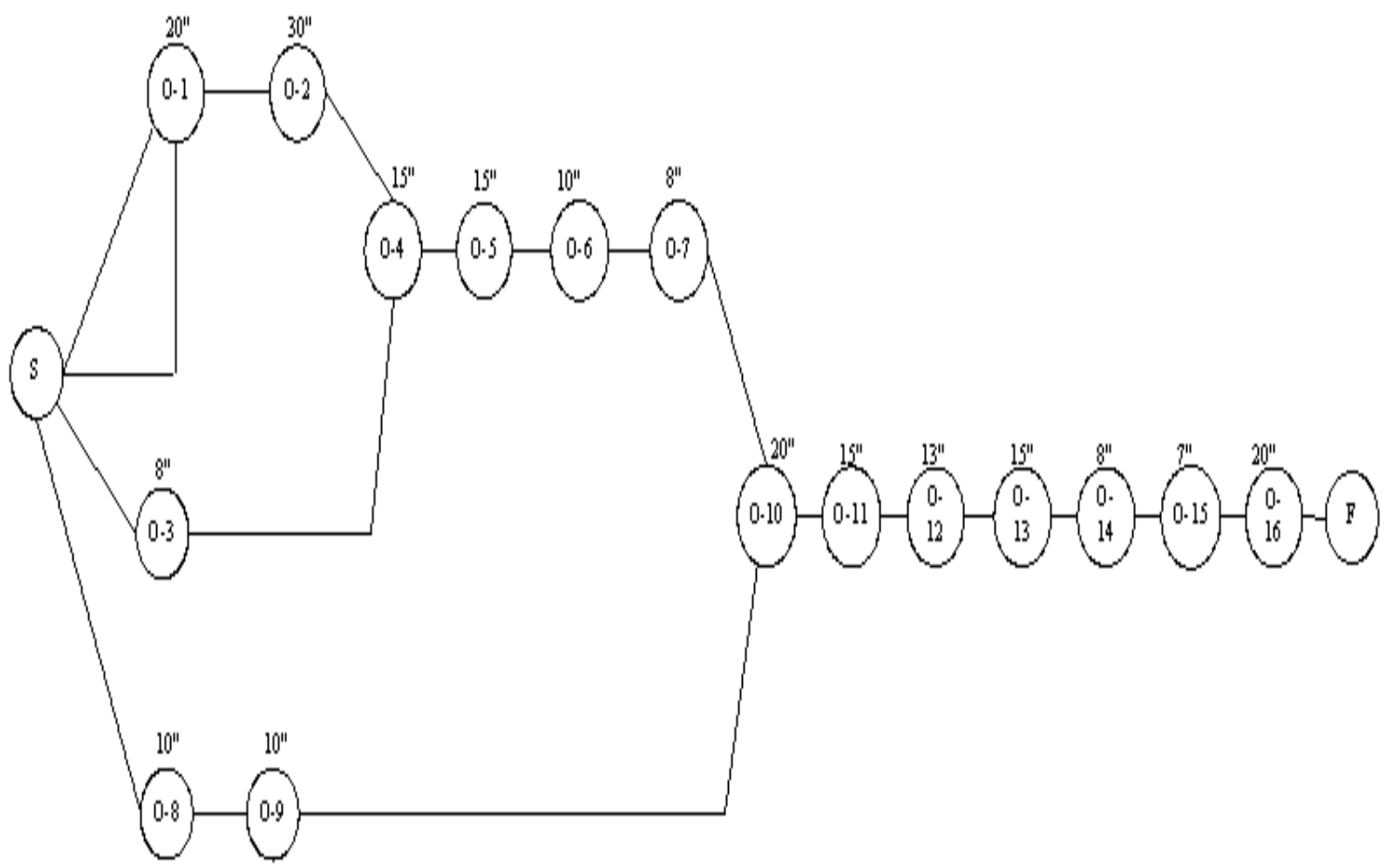

Sumber : Data Olahan

Gambar 4. Precedence Diagram Metode Hegelson - Birnie 
Pengelompokkan Operasi ke Dalam

\section{Work Station}

Tabel 1. Pengelompokkan Operasi Ke Dalam Work Station Dengan Metode Hegelson Birnie

Waktu

\begin{tabular}{|c|c|c|c|c|}
\hline Siklus & $=$ & 30 & Detik & \\
\hline $\begin{array}{c}\text { Work } \\
\text { Station } \\
\end{array}$ & $\begin{array}{c}\text { Oper } \\
\text { asi }\end{array}$ & $\begin{array}{l}\text { Waktu } \\
\text { Kerja }\end{array}$ & $\begin{array}{c}\% \% \\
\text { Efisiensi } \\
\end{array}$ & $\begin{array}{l}\text { Idle } \\
\text { Time }\end{array}$ \\
\hline I & 1.3 & 28 & 93.33 & 2 \\
\hline II & 2 & 30 & 100.00 & 0 \\
\hline III & 4.5 & 30 & 100.00 & 0 \\
\hline IV & $6,7,8$ & 28 & 93.33 & 2 \\
\hline $\mathrm{V}$ & 9,10 & 30 & 100.00 & 0 \\
\hline $\mathrm{VI}$ & 11.12 & 28 & 93.33 & 2 \\
\hline VII & $\begin{array}{c}13,14 \\
, 15 \\
\end{array}$ & 30 & 100.00 & 0 \\
\hline VIII & 16 & 20 & 66.67 & 10 \\
\hline & $\begin{array}{l}\text { TOT } \\
\text { AL }\end{array}$ & 224 & 746.67 & 16 \\
\hline
\end{tabular}

Rata - rata Efisiensi $=93.33 \%$

Idle Time $=16$ detik

Balance Delay $=6.67 \%$
Waktu Siklus $=30$ Detik

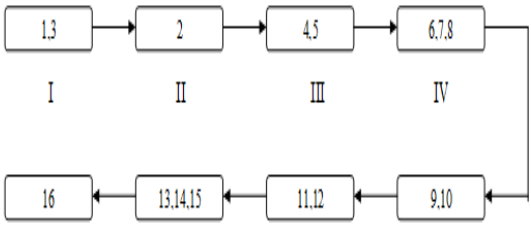

$\begin{array}{llll}\text { VII } & \text { VI } & \text { VI }\end{array}$

Gambar 5. Lintasan Perakitan Metode Hegelson - Birnie

Perhitungan Rata-rata Efisiensi, Idle Time, Balance Delay

$\Rightarrow$ Waktu Siklus $=30$ Detik

- Rata-rata Efisiensi $=\frac{\sum_{i=1}^{n} W i}{n \cdot W S} \times 100 \%$

$$
=(224 /(8 \times 30) \times 100 \%
$$$$
=93,33 \%
$$

- Idle Time

$$
=n \cdot W s-\sum_{i=1}^{n} W i
$$$$
=(8 \times 30)-224
$$$$
=16 \text { detik }
$$

- Balance Delay $=\frac{n . W s-\sum_{i=1}^{n} W i}{n . W S} \times 100 \%$

$=[[(8 \times 30)-(224)] /(8 \times 30)] \times 100 \%$

$=6,67 \%$

\section{Metode Killbridge - Wester}

\section{- Precedence Diagram}

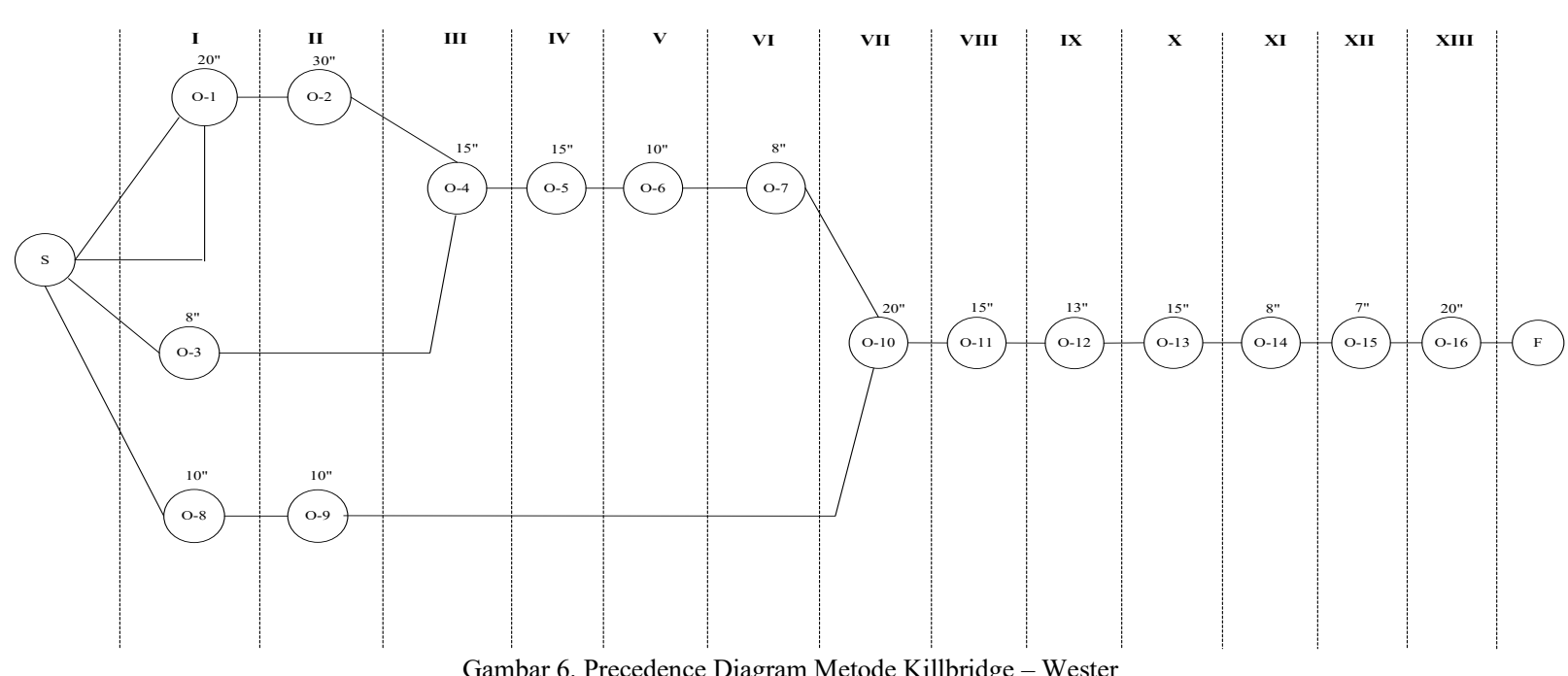




\section{ANALISA PENYEIMBANGAN LINTASAN PERAKITANPADA PROSES PEMBUATAN T-SHIRT DI \\ DEPARTEMEN ASSEMBLING DENGAN MENGGUNAKAN METODA HEGELSON - BIRNIE DAN METODA KILLBRIDGE - WESTER PT. CALADI LIMA SEMBILAN (C-59) BANDUNG}

\section{Pengelompokkan Operasi Ke Dalam Work $\underline{\text { Station }}$}

Tabel 2. Pengelompokkan Operasi Ke Dalam Work Station Metode Killbridge-Wester

Waktu siklus $=\mathbf{4 0}$ detik (diambil dari wilayah yang memiliki jumlah waktu operasi terbesar

\begin{tabular}{|c|c|c|c|c|}
\hline $\begin{array}{l}\text { Work } \\
\text { Station }\end{array}$ & Operasi & $\begin{array}{c}\text { Waktu } \\
\text { Kerja } \\
\text { (detik) }\end{array}$ & $\begin{array}{c}\% \\
\text { Efisiensi }\end{array}$ & $\begin{array}{l}\text { Idle } \\
\text { Time }\end{array}$ \\
\hline I & $1,3,8$ & 38 & 95.00 & 2 \\
\hline II & 2.9 & 40 & 100.00 & 0 \\
\hline III & $4,5,6$ & 40 & 100.00 & 0 \\
\hline IV & 7,10 & 28 & 70.00 & 12 \\
\hline $\mathrm{V}$ & 11.12 & 28 & 70.00 & 12 \\
\hline VI & $13,14,15$ & 30 & 75.00 & 10 \\
\hline \multirow[t]{2}{*}{ VII } & 16 & 20 & 50.00 & 20 \\
\hline & TOTAL & 224 & 560.00 & 56 \\
\hline
\end{tabular}

Rata-rata Efisiensi $=80.00 \%$

Idle Time $\quad=56$ detik

Balance Delay $\quad=20.00 \%$

$\Rightarrow$ Waktu Siklus $=40$ Detik

- Rata-rata Efisiensi $=\frac{\sum_{i=1}^{n} W_{i}}{n \cdot W_{S}} \times 100 \%$ $=(224 /(7 \times 40) \times 100 \%$ $=80,00 \%$

- Idle Time $=n . W s-\sum_{i=1}^{n} W i$

$$
=(7 \mathrm{x} 40)-224
$$$$
=56 \text { detik }
$$

- Balance Delay $=\frac{n \cdot W s-\sum_{i=1}^{n} W i}{n . W s} \times 100 \%$

$$
\begin{aligned}
& =\quad[[(7 \times 40)-(224)] /(7 \times 40)] \times 100 \% \\
& =\quad 20,00 \%
\end{aligned}
$$

\section{$\underline{\text { Lintasan Perakitan Metode Killbridge-Wester }}$}

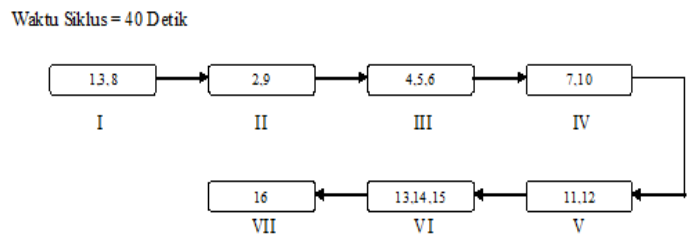

Gambar 7. Lintasan Perakitan Killbridge-Wester

Berdasarkan kriteria-kriteria umum yang digunakan untuk menganalisa keseimbangan lintasan perakitan yaitu : efisiensi lintasan (rata-rata efisiensi) yang maksimum, waktu menganggur (idle time) yang minimum, dan keseimbangan waktu senggang (balance delay) yang minimum, maka keseimbangan lintasan perakitan pembuatan T-Shirt di PT. Caladi Lima Sembilan (C-59) ini yang lebih baik digunakan yaitu metoda Hegelson-Birnie dengan waktu siklus 30 detik (waktu siklus berdasarkan waktu operasi terbesar).

Rata-rata efisiensi dengan waktu siklus 30 detik (waktu siklus berdasarkan waktu operasi terbesar) yaitu sebesar 93,33\%, artinya alternatif ini yang optimal dapat digunakan dalam perakitan pembuatan T-Shirt C59.

Waktu menganggur (idle time) dengan waktu siklus 30 detik (waktu siklus berdasarkan waktu operasi terbesar) yaitu 16 detik, artinya alternatif ini dapat menghindari atau mengurangi gejala bottle neck.

Keseimbangan waktu senggang (balance delay) dengan waktu siklus 30 detik (waktu siklus berdasarkan waktu operasi terbesar) yaitu sebesar $6,67 \%$, artinya keseimbangan waktu senggang pada lintasan perakitannya kecil. Adanya pengurangan jumlah stasiun kerja, yaitu dari 16 stasiun kerja sebelum penyeimbangan menjadi 8 stasiun kerja setelah penyeimbangan.

Metode Hegelson - Birnie merupakan metode yang terbaik digunakan, karena metode ini dilakukan dengan pendekatan programa dinamis, yang hasilnya mendekati optimal.

Dengan perhitungan perbandingan dari kapasitas produksi yang telah ada dengan kapasitas produksi yang akan dihasilkan dari adanya lintasan perakitan metoda Hegelson-Birnie, maka dapat dibuktikan dengan sebagai berikut :

1. Kapasitas Produksi perusahaan dalam setahun $=78750 \times 12=945000$ pieces

2. Waktu yang tersedia dalam satu tahun = 15120000 detik

3. Kapasitas Produksi dengan waktu siklus 30" dengan metoda Hegelson-Birnie dengan perhitungan sebagai berikut :

$\frac{\text { Jam Kerja yang tersedia }}{\text { Waktu siklus }}=\frac{15120000^{\prime \prime}}{30^{\prime \prime}}=504000$ pieces $/$ tahun

Perhitungan Kapasitas produksi dengan metoda Hegelson-Birnie menghasilkan sebesar 504000 pieces/tahun dengan 8 work station, maka untuk memenuhi kapasitas produksi yang diinginkan perusahaan dapat membuat lintasan produksi baru. Sehingga dengan menggunakan metoda Hegelson-Birnie dapat memperoleh kapasitas produksi sebesar : 504000 pieces/tahun x $2=1008000$ pieces/tahun.

Kapasitas produksi sebesar 1008000 pieces/tahun yang dihasilkan dari 2 lintasan perakitan metode Hegelson-Birnie, dapat melebihi target kapasitas produksi perusahaan. Sehingga tebukti bahwa dengan metoda Hegelson-Birnie akan memperoleh kapasitas 
produksi yang lebih besar jika dibandingkan dengan kondisi nyata perusahaan.

\section{KESIMPULAN}

Berdasarkan hasil pengolahan serta analisa dan pembahasan yang telah dilakukan, maka hasil yang disimpulkan adalah sebagai berikut :

1. Pada Metode Hegelson-Birnie dengan waktu siklus 30 detik diperoleh rata-rata efisiensi sebesar 93,33\% dengan idle time 16 detik dan balance delay sebesar $6,67 \%$, selain itu adanya pengurangan jumlah stasiun kerja dari 16 stasiun kerja menjadi 8 stasiun kerja. Hasil perhitungan dari metoda Metode Killbridge-Wester dengan waktu siklus 40 detik diperoleh rata-rata efisiensi sebesar 80,00\% dengan idle time 56 detik dan balance delay sebesar $20 \%$, selain itu adanya pengurangan jumlah stasiun kerja dari 16 stasiun kerja menjadi 7 stasiun kerja.

2. Pada proses pembuatan T-Shirt di unit Assembling Cigadung PT. Caladi Lima Sembilan (C-59), untuk memperoleh lintasan perakitan yang optimal sebaiknya dapat menggunakan metoda yang terbaik yaitu metoda Hegelson-Birnie (Rank Positional Weight). Dengan lintasan perakitan metode HegelsonBirnie, maka terbukti dapat menghasilkan kapasitas produksi yang lebih besar, yaitu sebesar 1008000 pieces/tahun, sehingga dapat membuat suatu lintasan perakitan baru.

\section{DAFTAR PUSTAKA}

Baker, Kenneth R., Introduction To Sequencing and Scheduling, John Willey \& Sons Inc., New York, Chicester, Brisbane, Toronto, Singapore, 1974.

Bedworth, David D., Bailey, James E., Integrated Production Control Systems, $2^{\text {nd }}$ Edition, John Willey \& Sons Inc., Singapore, 1987.

Biegel, John E., Production Control, A Quantitative Approach, Second Edition, Prentice-Hall of India Private Limited, New Delhi, 1990.

Dilworth, J. B., 2013. Production and Operation Management. $5^{\text {th }}$ Edition. Singapore : McGraw-Hill.

Garg, P. (2010). "Production And Operations Management".1st Edition, S.K. Kataria \& Sons.

Gaspersz, Vincent. 2005. Production Planning And Inventory Control: Berdasarkan Pendekatan Sistem Teritegrasi MRP II dan JIT Menuju Manufacturing 21, Penerbit Gramedia Pustaka Utama, Jakarta.

Heizer, Jay dan Barry Render, 2010. Operations Management - Manajemen Operasi. Edisi 9 Buku 2. Jakarta : Salemba Empat
Kriengkorakot Nuchsara and Piantong Nalin. 2007. The Assembly Line Balancing Problem : review articles. International Journal of Production Research, vol. 34 no.2 (133140) march - april 2007.

Nasution, A. H., 2009. "Perencanaan dan Pengendalian Produksi”, Institut Teknologi sepuluh november, Surabaya.

Prihanti, Sekar, Gita. 2017. Pengantar Tenik Industri. Universitas Muhammadiyah Malang (UMM).

Purnomo, Hari. Pengantar Teknik Industri. Yogyakarta: Graha Ilmu. 2004.

Prabowo Roni. Penerapan Konsep Line Balancing untuk mencapai efisiensi kerja yang optimal pada setiap stasiun kerja pada PT. HM. Sampoerna Tbk. ISSN. 1411-7010. volume 20 no.2, desember 2016.

Sutalaksana, Anggawisastra, Tjakraatmaja, Teknik Tata Sistem Kerja, Jurusan Teknik Industri ITB, Bandung, 2012.

Wignjosoebroto, Sritomo. Teknik Tata Cara dan Pengukuran Kerja, Jakarta : Guna Widya. 2009.

\section{RIWAYAT PENULIS}

Dini Yulianti, penulis kelahiran Bandung 16 Juli 1979. Memperoleh gelar Sarjana Teknik (ST), Jurusan Teknik Industri Universitas Pasundan, lulus tahun 2003. Memperoleh gelar Magister Teknik (MT) Program Pasca Sarjana Magister Teknik Industri Universitas Pasundan, lulus tahun 2015. Menjadi Dosen tetap yayasan di Universitas Bandung Raya Fakultas Teknik dari tahun 2005. Homebase NIDN 0416077901 pada Jurusan Teknik Industri Universitas Bandung Raya Jl, Banten no.11 Bandung. Email diniyulianti_17@yahoo.com. 